\title{
Are You with the Globalists or Patriots?
}

\author{
The Temptation of a Trump-Style \\ Foreign Policy Choice
}

Oleg N. Barabanov

Donald Trump's remarks at the 74th Session of the UN General Assembly quickly became famous: "If you want democracy, hold on to your sovereignty. And if you want peace, love your nation. Wise leaders always put the good of their own people and their own country first. The future does not belong to globalists. The future belongs to patriots." Thus, the ideology of Trumpism has been enriched, let us admit it, with a vivid and hard-hitting media image that characterizes its foreign policy dimension.

He devoted much of his UN address to domestic economic growth in the United States as the basis of Trumpism's success. America's economic achievements in recent years (regardless of whether they are rooted in Trump's own efforts or represent Obama's delayed legacyl are confirmed by objective statistics and indices. A case in point is the Valdai Club's recent Future Preparedness Index that gives the U.S. a high ranking.

At the same time, the U.S. president has imparted to Trumpism a clear international and even global dimension as the only alternative to the West's entire previous foreign policy. It also transpired from his remarks that this alternative in all of its aspects was a much

Oleg N. Barabanov, a Russian historian and political scientist, is Program Director of the Valdai International Discussion Club. Club. This article is an abridged version of the paper written for the Valdai Club. The original version is available at: http://valdaiclub.com/a/ highlights/are-you-with-the-globalists-or-with-the-patriots/

DOI: 10.31278/1810-6374-2019-17-4-199-202 
better option for the non-Western countries in their need of growth, development, influence and security.

Highly indicative in this regard was the string of bilateral meetings that Donald Trump held with Asian leaders on the sidelines of the UN General Assembly. Many of these were based on his contrasting the "mess" created by the Obama administration with his own achievements. For example, this was the keynote of his meeting with President of Iraq Barham Salih. Referring to the fight against ISIS, Trump (during an open part of this meeting) stressed that Obama was to blame for the "big mess," hinting at suspicions that the Obama-Clinton administrations had been behind the growth of radical segments of Muslim Brotherhood that later gave rise to ISIS. The fact that the "caliphate" is now totally defeated is Trump's doing. The message is clear: It is only Trump and the Trumpist United States that will be your true defender.

The same logic can be traced in Trump's decision to support Saudi Arabia in its conflict with Qatar. In many respects, it was caused by the fact that Qatar had been strongly supported by the Obama administration, whereas Qatar's support for Muslim Brotherhood radicals had motivated the Saudis and their partners to accuse Qatar of backing terrorism. Thereby Trump makes it clear that the destabilization in the Arab world is a consequence of the conscious course chosen by the "globalists" from the Democratic Party, who decided to play with fire. At the same time, the "patriots," including himself, are in favor of the status quo and unwilling to press their partners, be it traditional (the Saudis) or new (Iraq), for far-fetched globalist motives.

As a result, Trump is offering other countries' leaders an alternative and a choice between the two sides in the current and future world politics: the globalists or the patriots. The price of this choice to be paid is "merely" the level of relations with Trump's United States. So, the temptation to make the correct choice is quite obvious.

The same choose-choose policy is conducted by Trump in Europe, which epitomizes the Global West. It has scored a signal success in Poland, where the "patriots" in the person of Kaczyński, Duda and their loyalists are in conflict with the "globalists" from the EU and enthusiastic about the Trump alternative. As a result, 
Poland is being positioned as the bulwark of Trump-style patriots inside the EU.

Trump has maneuvered Ukraine under new President Zelensky into a position where it has to make the choice as well. The situation is highly scandalous because the Ukrainian choice-making is linked to finding sensitive information on Joe Biden. Judging by the declassified transcript of the Trump-Zelensky telephone conversation, the Ukrainian president is fully aware of the alternative and, in principle, is ready to accommodate Trump "with no pressure" on his part.

The important thing is that Vladimir Zelensky seemed sincere when he said that "there was no pressure" during his personal meeting with Trump on the sidelines of the UN General Assembly. It is just that the prospects for relations with the leading world power in the event of this or that choice are so obvious that one may be involuntarily tempted to make the "right choice." What Trump told Zelensky ("Your economy is going to get better and better I predict.") is a carrot that goes along with the "right choice." No pressure, just temptation.

Besides, Trump's "patriotism" is in high demand where elites of a country base their ideology and electoral values on nationalism and stronger sovereignty motives. This applies to the EU revisionists (Poland, Hungary, Italy under Salvini), whose strategy is to contrast their fight for "patriotism" with Brussels' supranational policies. This also refers to India under Modi and Israel under Netanyahu, where right-wing civic nationalism is the basis of official discourse and policies. For them, the temptation of Trump-offered choice is not only natural but also represents absolutely essential outside support for their own course. When this support is being offered by the leading world power, it is exactly what they need. Therefore, numerous states seeking to strengthen their influence in the world choose Trump. In a nutshell, if you want to grow and be important in the world, be a Trump-style patriot.

As is only natural, this choice-related temptation has limitations of its own. Obviously, it is a rhetorical exaggeration to say "Trump's United States." There are many well-known arguments in favor of the contention that the U.S. or, to be more precise, the U.S. elites are against Trump. And that Trump and his discourse are just a quirk of 
fate that will be dispelled after the 2020 election. In this connection, one can also understand the no-nonsense hints that the tempted countries will soon have to repent. President Zelensky knows this better than anyone.

But Trump's entire life shows that he will not surrender without a fight. For this reason, the upcoming presidential election in the U.S. is acquiring a huge global dimension, where all countries lat least their public and, in many cases, their elites) are feeling both the Trumpist temptation and the fear of responsibility. This combination in itself can create additional support for Trump in the world, because with him gone, the alternative so much desired by many will disappear as well-in the East, in the developing world as a whole, and in the West itself too. 